\title{
Reference gene selection for quantitative PCR studies in bovine neutrophils
}

\author{
William R. Vorachek ${ }^{1}$, Gerd Bobe ${ }^{2}$, Jean A. Hall ${ }^{1}$ \\ ${ }^{1}$ Department of Biomedical Sciences, College of Veterinary Medicine, Oregon State University, Corvallis, USA \\ ${ }^{2}$ Department of Animal and Rangeland Sciences, College of Agricultural Sciences, Linus Pauling Institute, Oregon State University, \\ Corvallis, USA \\ Email: Jean.Hall@oregonstate.edu
}

Received 30 June 2013; revised 31 July 2013; accepted 2 August 2013

Copyright (C) 2013 William R. Vorachek et al. This is an open access article distributed under the Creative Commons Attribution License, which permits unrestricted use, distribution, and reproduction in any medium, provided the original work is properly cited.

\begin{abstract}
Reference genes are essential for studying mRNA expression with quantitative PCR (qPCR). We investigated 11 candidate whole-blood neutrophil reference genes (ACTB, B2M, G6PD, GAPDH, GYPC, HPRT, PGK1, RPL19, SDHA, TFRC, and YWHAZ) for beef calves, both males and females, with or without selenium supplementation. Initial screening was based on gene expression level ( $<28$ Cq cycles), variability (SD < 1.5 Cq cycles), excluded GYPC and TFRC from further analysis. Expression stability of the remaining genes was evaluated using four software programs: geNorm, NormFinder, BestKeeper, and the comparative delta Cq method. The neutrophil reference genes, YWHAZ, PGK1, and RPL19, consistently ranked among the top four most stable genes under these experimental conditions. The commonly used reference genes, ACTB and HPRT, were not reliable, underscoring the need to validate neutrophil reference genes under different experimental conditions. Multiple reference genes rather than a single gene may provide more robust and reliable results. The best pair of reference genes in whole-blood neutrophils from beef calves overall was PGK1|YWHAZ.
\end{abstract}

Keywords: Blood Neutrophils; Bos taurus; qPCR; Reference Genes; Selenium Treatment

\section{INTRODUCTION}

Quantitative PCR (qPCR) is one of the most common techniques used for evaluating gene expression [1]. To adjust for differences in total RNA concentrations, data are normalized against RNA levels of internal control genes, also called reference genes or housekeeping genes. Reference genes are assumed to be constitutively ex- pressed in the tissue or cell type of interest at concentrations similar to genes of interest; however, their RNA levels may vary depending on tissue or cell type analyzed as well as experimental conditions [2-5]. Therefore, it is essential to evaluate reference genes in the same type of tissue and under similar experimental conditions before using them to adjust RNA levels for genes of interest.

Our interest is in studying the effects of supranutritional selenium (Se) supplementation on immune function in ruminants. We previously reported in sheep that supranutritional Se-yeast supplementation alters wholeblood (WB) neutrophil gene expression profiles [6]. Neutrophils are the most numerous and important cellular component of innate immunity. They serve as the body's first line of defense against invading microorganisms. Neutrophils use two general mechanisms to kill microorganisms: extracellular killing via neutrophil extracellular traps [7-9], or intracellular killing via phagocytosis followed by the secretion of antimicrobial proteins, proteolytic enzymes, and reactive oxygen species when membrane-bound granules fuse with phagocytic vesicles. We and others have reported on potential reference genes in human $[10,11]$ and ovine neutrophils $[12,13]$. In one study with human neutrophils, suitable reference genes included a TATA box binding protein (TBP), beta-actin (ACTB), and succinate dehydrogenase complex subunit A (SDHA) [11]. In another human study, guanine nucleotide binding protein, $\beta$-peptide 2-like1 (GNB2L1), hypoxanthine phosphoribosyl-transferase 1 (HPRT), ribosomal protein L32 (RPL32), ACTB, and beta-2-microglobulin (B2M) were suggested as suitable reference genes in gene expression studies of neutrophils [10]. In sheep neutrophils, we found that SDHA and glucose-6phosphate dehydrogenase (G6PD) in healthy sheep, and glyceraldehyde-3-phosphate dehydrogenase (GAPDH) 
and tyrosine 3-monoxygenase/tryptophan 5-monooxygenase activation protein zeta polypeptide (YWHAZ) in foot rot diseased sheep were the best pairs of references genes [13]. In ovine whole blood, SDHA and YWHAZ were considered the most suitable reference genes as they were stably expressed regardless of disease status [12]. In the bovine, potential reference genes have been evaluated in polymorphonuclear leukocytes [14], mammary epithelial cells [15], adipose tissue [16], milk somatic cells [17], and WB-cells [18] of lactating dairy cows, and in muscular tissue [19]; however, to our knowledge, potential reference genes have not been evaluated in WB-neutrophils under conditions of Se supplementation in growing beef calves.

Therefore, we investigated 11 potential neutrophil reference genes (Table 1) including: ACTB, B2M, G6PD, GAPDH, glycophorin C (GYPC), HPRT, phosphoglycerate kinase 1 (PGK1), ribosomal protein L19 (RPL19), SDHA, transferrin receptor (TFRC), and YWHAZ. We assessed gene expression levels, and analyzed gene expression stability using the programs geNorm [20], Norm Finder [21], BestKeeper [22], and a comparative delta $\mathrm{Cq}$ method [23], in WB neutrophils from beef calves, males and females, with or without Se supplementation, and in both treatment groups combined.

\section{MATERIALS AND METHODS}

\subsection{Candidate Genes for Expression Studies}

Eleven genes were selected from commonly used reference genes [11]: ACTB, B2M, G6PD, GAPDH, GYPC, HPRT, PGK1, RPL19, SDHA, TFRC, and YWHAZ. The length of the primers ranged from 18-bp to 27-bp, GC content varied from $45 \%$ to $60 \%$, and the expected PCR product size was 71-bp to 126-bp (Table 2). Table 2 summarizes primer information including $R^{2}$ and efficiency of qPCR analysis. The Minimum Information for Publication of Quantitative Real-Time PCR Experiments guidelines (MIQE) were followed for sample handling and analysis [24] and a checklist is available in the supplementary file.

Reference genes were selected based upon a literature review to find genes that covered a wide variety of functions and pathways: ACTB, GAPDH, and B2M [19]; HPRT, SDHA, and YWHAZ [14], RPL19 [25], and four commonly used ovine neutrophil reference genes (G6PD, TFRC, PGK1, and GYPC) [12,13]. All primers were synthesized by Sigma Aldrich (St. Louis, MO) and purified by desalting. To verify that these primers were bovine specific, each primer pair was used to amplify bovine cDNA (AccuPrime Taq; Applied Biosystems, Foster

Table 1. Candidate reference genes evaluated in this study.

\begin{tabular}{|c|c|c|c|c|}
\hline Gene symbol & Gene name & Function & Accession number* & Gene synonyms \\
\hline ACTB & Beta-actin & Cytoskeletal structural protein & NM_173979.3 & $\begin{array}{l}\text { Actin cytoplasmic } 1 \text {; } \\
\text { beta-actin }\end{array}$ \\
\hline B2M & Beta-2-microglobin & $\begin{array}{l}\text { Beta-chain of class I major } \\
\text { histocompatibility complex molecules }\end{array}$ & NM_173893.3 & \\
\hline G6PD & $\begin{array}{l}\text { Glucose-6-phosphate } \\
\text { dehydrogenase }\end{array}$ & Enzyme in carbohydrate metabolism & NM_001244135.1 & \\
\hline GAPDH & $\begin{array}{l}\text { Glyceraldehyde-3-phosphate } \\
\text { dehydrogenase }\end{array}$ & Enzyme in carbohydrate metabolism & NM_001034034.2 & GAPD; G3PDH \\
\hline GYPC & Glycophorin C & Integral $\mathrm{RBC}$ membrane binding protein & NM_001002886.1 & $\begin{array}{l}\text { BOS_1916; CD236; } \\
\text { D236R }\end{array}$ \\
\hline HPRT & $\begin{array}{l}\text { Hypoxanthine } \\
\text { phosphoribosyl-transferase } 1\end{array}$ & $\begin{array}{l}\text { Phosphoribosyl-transferase (PRT)-type I } \\
\text { domain }\end{array}$ & NM_001034035.2 & HPRT1 \\
\hline RPL19 & Ribosomal protein L19 & Found in the large ribosomal subunit & NM_001040516.1 & \\
\hline SDHA & $\begin{array}{l}\text { Succinate dehydrogenase complex, } \\
\text { subunit A }\end{array}$ & Mitochondrial respiratory chain & NM_174178.2 & \\
\hline TFRC & Transferrin receptor & $\begin{array}{l}\text { Protease-associated domain containing } \\
\text { proteins, like transferrin receptors }\end{array}$ & NM_001206577.1 & p90; CD71 \\
\hline YWHAZ & $\begin{array}{l}\text { Tyrosine } 3 \text {-monoxygenase/ } \\
\text { tryptophan 5-monooxygenase } \\
\text { activation protein, zeta polypeptide }\end{array}$ & $\begin{array}{l}\text { Signal transduction by binding to } \\
\text { phosphoserine containing proteins }\end{array}$ & NM_174814.2 & $\begin{array}{l}\text { 14-3-3 protein zeta/delta; } \\
\text { tyrosine } \\
\text { 3-monooxygenase }\end{array}$ \\
\hline
\end{tabular}

*NCBI Reference Sequence database http://www.ncbi.nlm.nih.gov/RefSeq/. 
Table 2. Characteristics of the primers of the 11 candidate reference genes used for qPCR analysis.

\begin{tabular}{|c|c|c|c|c|c|}
\hline Gene symbol & Primer sequences (forward/reverse) & Spanned Exons & Amplicon size (bp) & $R^{2}$ & PCR Efficiency \\
\hline ACTB & $\begin{array}{l}\text { AAGGCCAACCGTGAGAAGATGACC } \\
\text { TGTCACGCACAATTTCCCGCTC }\end{array}$ & $\begin{array}{l}2^{\text {nd }} \\
3^{\text {rd }}\end{array}$ & 97 & 0.98 & 0.94 \\
\hline B2M & $\begin{array}{l}\text { CTGTCGCTGTCTGGACTGG } \\
\text { TTTGGCTTTCCATCTTCTGG }\end{array}$ & $1^{\text {st }}$ & 86 & 1.00 & 1.02 \\
\hline G6PD & $\begin{array}{l}\text { TGACCTATGGCAACCGATACAA } \\
\text { CCGCAAAAGACATCCAGGAT }\end{array}$ & $\begin{array}{l}10^{\text {th }} \\
11^{\text {th }}\end{array}$ & 76 & 1.00 & 1.03 \\
\hline GAPDH & $\begin{array}{l}\text { ATGCCTCCTGCACCACCA } \\
\text { AGTCCCTCCACGATGCCAA }\end{array}$ & $\begin{array}{l}7^{\text {th }} \\
8^{\text {th }}\end{array}$ & 86 & 0.99 & 1.35 \\
\hline GYPC & $\begin{array}{l}\text { ATCAACATCGCTGTCATTGC } \\
\text { CTCGTTGGTGTCCTATGTGC }\end{array}$ & $4^{\text {rd }}$ & 117 & 0.97 & 1.55 \\
\hline HPRT & $\begin{array}{l}\text { TTTATTCCTCATGGACTTAATTATGGA } \\
\text { CCACCCATCTCCTTCATCAC }\end{array}$ & $\begin{array}{l}4^{\text {th }} \\
5^{\text {th }}\end{array}$ & 71 & 0.99 & 1.02 \\
\hline RPL19 & $\begin{array}{l}\text { AGCCTGTGACTGTCCATTCC } \\
\text { ACGTTACCTTCTCGGGCATT }\end{array}$ & $\begin{array}{l}2^{\text {nd }} \\
3^{\text {rd }}\end{array}$ & 126 & 0.99 & 1.00 \\
\hline PGK1 & $\begin{array}{l}\text { ACTCCTTGCAGCCAGTTGCT } \\
\text { AGCACAAGCCTTCTCCACTTCT }\end{array}$ & $4^{\text {rd }}$ & 101 & 1.00 & 0.87 \\
\hline SDHA & $\begin{array}{l}\text { CATCCACTACATGACGGAGCA } \\
\text { ATCTTGCCATCTTCAGTTCTGCTA }\end{array}$ & $\begin{array}{l}4^{\text {th }} \\
5^{\text {th }}\end{array}$ & 90 & 0.98 & 1.74 \\
\hline TFRC & $\begin{array}{l}\text { TTCTGGGCAGACCTCAAATC } \\
\text { CAGCTTCACGTGGGACATAA }\end{array}$ & $4^{\text {th }} 5^{\text {th }}$ & 106 & 0.91 & 0.99 \\
\hline YWHAZ & $\begin{array}{l}\text { TGTAGGAGCCCGTAGGTCATCT } \\
\text { TTCTCTCTGTATTCTCGAGCCATCT }\end{array}$ & $\begin{array}{l}2^{\text {nd }} \\
3^{\text {rd }}\end{array}$ & 123 & 1.00 & 0.89 \\
\hline
\end{tabular}

City, CA). The following conditions were employed: $94^{\circ} \mathrm{C}$ for $2 \mathrm{~min}$; then 35 cycles of $94^{\circ} \mathrm{C}$ for $30 \mathrm{~s}, 60^{\circ} \mathrm{C}$ for $30 \mathrm{~s}$, and $68^{\circ} \mathrm{C}$ for $30 \mathrm{~s}$. The PCR products were then purified using a QIAquick PCR Purification Kit (Qiagen Sciences, Germantown, MD) according to manufacturer's instructions, and quantitated using an ND-1000 NanoDrop Spectrophotometer (Thermo Fisher Scientific; Waltham, MA). The PCR products were subsequently sequenced at the Oregon State University Center for Genome Research and Biocomputing (Corvallis, OR) using an automated ABI 3100 capillary sequencer (Applied Biosystems). The sequences obtained were used in a BLAST search (National Center for Biotechnology Information, US National Library of Medicine, Bethesda, MD) to verify that the products were bovine in origin and were amplifying genes of interest.

\subsection{Whole-Blood Collection}

Calves were bled after feeding Se-enriched alfalfa hay for 6 or 7 weeks, as part of a study that has been previously reported [26]. The experimental protocol was reviewed and approved by the Oregon State University Animal Care and Use Committee. Jugular venous blood was collected into evacuated ethylenediaminetetraacetic acid (EDTA) tubes $(10 \mathrm{~mL}$; final EDTA concentration 2 $\mathrm{g} / \mathrm{L}$; Becton Dickinson, Franklin Lakes, NJ) and stored on ice until transported to the lab for neutrophil isolation.

\subsection{Neutrophil Isolation}

Neutrophils were isolated within $4 \mathrm{~h}$ of collection, using a Percoll (Sigma-Aldrich, St. Louis, MO) gradient technique, then resuspended in $1 \times$ Hank's balanced saline solution (HBSS; Life Technologies, Grand Island, NY) plus $0.5 \%$ fetal bovine serum (FBS; Life Technologies). Cells were counted using a Coulter counter (Beckman Coulter, Indianapolis, IN) to determine cell concentration. Briefly, $10 \mathrm{~mL}$ of anticoagulated blood was transferred into 50$\mathrm{mL}$ tubes (Thermo Fisher Scientific) and centrifuged at $1000 \times \mathrm{g}$ in a TJ-6 swinging bucket centrifuge (Beckman Coulter) for $20 \mathrm{~min}$ at $22^{\circ} \mathrm{C}$. The plasma, buffy coat, and one third of the RBC pack from each tube were aseptically removed. The remaining RBC pack and leukocytes were mixed with 34-mL ice-cold PBS (Life Technologies) and layered onto $10 \mathrm{~mL}$ of freshly prepared $1.084 \mathrm{~g} / \mathrm{mL}$ Percoll. Tubes were centrifuged at $400 \times \mathrm{g}$ for $40 \mathrm{~min}$ at $22^{\circ} \mathrm{C}$. After centrifugation, $\mathrm{RBC}$ and neutrophils pelleted at the bottom of the tube and the mononuclear cell band remained at the sample/medium interface.

Neutrophils were isolated after removing the mononuclear cell band; all layers above the RBC pack were aspirated and discarded. The RBC were lysed using $24-\mathrm{mL}$ ice-cold hypotonic lysis buffer $\left(10.56 \mathrm{mM} \mathrm{Na} \mathrm{HPO}_{4}\right.$, $2.67 \mathrm{mM} \mathrm{NaH}_{2} \mathrm{PO}_{4}, \mathrm{pH} 7.3$ ) for $90 \mathrm{~s}$, and then isotonicity was restored by adding $12-\mathrm{mL}$ ice-cold hypertonic restore buffer $\left(10.56 \mathrm{mM} \mathrm{Na} 2 \mathrm{HPO}_{4}, 2.67 \mathrm{mM} \mathrm{NaH}_{2} \mathrm{PO}_{4}\right.$, $0.43 \mathrm{M} \mathrm{NaCl}, \mathrm{pH}$ 7.3) to stop lysis. Neutrophils were pelleted by centrifugation of tubes at $800 \times \mathrm{g}$ for $5 \mathrm{~min}$ at $22^{\circ} \mathrm{C}$ in a TJ-6 centrifuge. The lysis solution was decanted, and the neutrophils were resuspended and washed twice more with $1 \times$ HBSS plus $0.5 \%$ FBS. The neu- 
trophils were then resuspended in $0.25 \mathrm{~mL}$ of $1 \times$ HBSS with $0.5 \%$ FBS and stored on ice until needed. A $20-\mu \mathrm{L}$ aliquot of the cell suspension was used to determine cell concentration using a Coulter counter (Beckman). Another $5-\mu \mathrm{L}$ aliquot was used to assess purity of neutrophil preparations (differential cell count) by microscopic examination after Wright-Giemsa staining $(96 \% \pm 1 \%$ neutrophils; mean $\pm \mathrm{SEM}$ ). The remaining neutrophils were pelleted by centrifugation at $700 \times \mathrm{g}$ for $10 \mathrm{~min}$ at $4^{\circ} \mathrm{C}$ in a TJ-6 swinging bucket rotor (Beckman), supernatant was removed, and cells were frozen at $-80^{\circ} \mathrm{C}$.

\subsection{RNA Isolation}

Total RNA was extracted from previously frozen neutrophils using an RNeasy ${ }^{\circledR}$ Mini Kit (Qiagen Sciences) according to manufacturer's instructions. Genomic DNA was eliminated with an RNase-Free DNase (Qiagen Sciences) digestion. Total isolated RNA was quantified using an ND-1000 NanoDrop Spectrophotometer (Thermo Fisher Scientific). Only samples with $\mathrm{A}_{260} / \mathrm{A}_{280}$ ratios between 1.40 and 2.16 were analyzed further. Samples were stored at $-80^{\circ} \mathrm{C}$ until needed.

\subsection{Quantitative PCR}

Expression level of references genes in neutrophils was determined by qPCR. First-strand cDNA was synthesized from $50 \mathrm{ng}$ of total RNA from each sample using the High Capacity cDNA Reverse Transcription Kit (Applied Biosystems). Subsequent qPCR was conducted using RT2 SYBR Green qPCR Mastermix (Qiagen Sciences) in 96well MicroAmp ${ }^{\circledR}$ reaction plates (Applied Biosystems) with a final reaction volume of $25 \mu \mathrm{L}$. Each well contained $12.5 \mu \mathrm{L}$ of qPCR Mastermix, $1 \mu \mathrm{L}$ of each primer, $1 \mu \mathrm{L}$ of cDNA sample, and $9.5 \mu \mathrm{L}$ of PCR-grade water. Abundance of gene transcripts was determined by absolute qPCR using the 7300 Real-time PCR System (Applied Biosystems). A negative control (containing all reagents except target DNA) was included to verify the absence of contamination in each qPCR assay. Each reaction consisted of the following steps: $10 \mathrm{~min}$ initial denaturation at $95^{\circ} \mathrm{C}$ to activate the polymerase; followed by 40 cycles of $15 \mathrm{~s}$ denaturation at $95^{\circ} \mathrm{C}$ and $1 \mathrm{~min}$ annealing-elongation at $60^{\circ} \mathrm{C}$. For each primer, PCR efficiency and $R^{2}$ were calculated using a standard curve derived from a pooled cDNA mixture serially diluted 4-fold over 4 measuring points, with two replications at each measuring point.

\subsection{Statistical Analysis of Neutrophil Gene Expression Stability}

The $\mathrm{Cq}$ values were reported as mean, standard deviation (SD), and range. Expression stability of potential neu- trophil reference genes was evaluated using generally accepted Excel-based software tools [24] according to instructions provided by the program developers, i.e., geNorm [20], NormFinder [21], BestKeeper [22], and a comparative delta $\mathrm{Cq}$ method [23]. Ranking of potential neutrophil reference genes was performed for neutrophils collected from calves fed alfalfa hay that was not enriched with $\mathrm{Se}$ (calves consumed $0.95 \mathrm{mg} \mathrm{Se} / \mathrm{head} /$ day) and calves fed Se-enriched alfalfa hay (calves consumed $18.76 \mathrm{mg} \mathrm{Se} /$ head/day). To provide a summary statistic for the four algorithms, the geometric mean of the ranking for each of the four algorithms was calculated [27]; the gene with the lowest value was viewed as the most stable reference gene. Normality of gene expression was tested using the Shapiro Wilk statistic in SAS, version 9.2 (SAS, Inc., Cary, NC, USA) software. Group averages of $\mathrm{Cq}$ values were compared overall, between male and female calves, between calves fed alfalfa hay that was Se-enriched or not, and between blood samples taken on two different dates (PROC GLM). The $R^{2}$ and efficiency were calculated as previously described [24]. All tests were two-sided. Statistical significance was declared at $P$ $\leq 0.05$.

\section{RESULTS AND DISCUSSION}

\subsection{Expression Level of Neutrophil Reference Genes Evaluated in This Study}

To identify the most appropriate set of reference genes for gene expression analyses in WB neutrophils of growing beef calves in the context of Se supplementation, a systematic investigation of 11 commonly used reference genes (Table 1) was performed by qPCR experiments. The 11 potential reference genes covered a variety of pathways to avoid bias from co-regulation among them [20]. The observed $\mathrm{Cq}$ values were distributed over a wide range in beef calf neutrophils (Table 3 ), including highly expressed $\mathrm{B} 2 \mathrm{M}(\mathrm{Cq} \pm \mathrm{SD}, 17.61 \pm 0.62 ; \mathrm{Cq}$ range, 2.62) and less transcribed TFRC $(29.83 \pm 0.88 ; \mathrm{Cq}$ range, 3.22$)$ and GYPC (31.52 $\pm 0.78 ; \mathrm{Cq}$ range, 2.80). The least variation was associated with YWHAZ $(22.49 \pm 0.35 ; \mathrm{Cq}$ range, 1.23) and the most variation was associated with ACTB (22.44 $\pm 1.06 ;$ Cq range, 3.85). Three genes did not pass the test for normal distribution at $P \leq 0.01$, namely SDHA (Shapiro-Wilk W $=0.87 ; P=0.008$ ), B2M (Shapiro-Wilk $\mathrm{W}=0.82 ; P=0.001$ ), and HPRT (ShapiroWilk $\mathrm{W}=0.87 ; P=0.007)$. None of the 11 genes evaluated differed significantly by sex of calf or Se supplementation.

We arbitrarily selected a gene expression level $>28$ cycles or high variability ( $\mathrm{SD}>1.5$ cycle) for exclusion of potential reference genes from further consideration. This eliminated GYPC and TFRC from further analysis. Our 
Table 3. Individual $\mathrm{Cq}$ values of the candidate reference genes in weaned beef calves fed for 6 or 7 weeks $0.96 \mathrm{mg} \mathrm{Se} /$ head/day (Control), $18.76 \mathrm{mg} \mathrm{Se} /$ head/day (High Selenium), or combined groups.

\begin{tabular}{ccccccc}
\hline $\begin{array}{c}\text { Gene } \\
\text { symbol }\end{array}$ & \multicolumn{2}{c}{$\begin{array}{c}\text { Calves, control } \\
(\mathbf{n}=\mathbf{1 0})\end{array}$} & \multicolumn{2}{c}{$\begin{array}{c}\text { Calves, high } \\
\text { selenium }(\mathbf{n}=\mathbf{1 2})\end{array}$} & \multicolumn{2}{c}{$\begin{array}{c}\text { Combined groups } \\
(\mathbf{n}=\mathbf{2 2})\end{array}$} \\
\hline & Mean Cq & SD & Mean Cq & SD & Mean Cq & SD \\
\hline ACTB & 22.07 & 0.78 & 22.74 & 1.19 & 22.44 & 1.06 \\
B2M & 17.31 & 0.24 & 17.85 & 0.73 & 17.61 & 0.62 \\
G6PD & 21.21 & 0.59 & 21.74 & 0.75 & 21.50 & 0.72 \\
GAPDH & 19.96 & 0.73 & 20.18 & 0.74 & 20.08 & 0.73 \\
GYPC & 31.64 & 0.82 & 31.43 & 0.76 & 31.52 & 0.78 \\
HPRT & 27.74 & 0.49 & 27.20 & 0.83 & 27.44 & 0.73 \\
PGK1 & 23.06 & 0.52 & 23.32 & 0.45 & 23.20 & 0.49 \\
RPL19 & 20.85 & 0.48 & 20.90 & 0.52 & 20.88 & 0.49 \\
SDHA & 25.55 & 0.59 & 25.62 & 0.60 & 25.58 & 0.58 \\
TFRC & 30.05 & 0.78 & 29.64 & 0.95 & 29.83 & 0.88 \\
YWHAZ & 22.43 & 0.29 & 22.55 & 0.40 & 22.49 & 0.35 \\
\hline
\end{tabular}

rationale was that the delta $\mathrm{Cq}$ for genes of interest compared to reference genes in subsequent studies would be more accurate if reference genes were expressed in sufficient copy numbers to be reliably detected in all samples and have limited variation.

\subsection{GeNorm Analysis of Reference Genes}

The program geNorm [20] provides a measure of gene expression stability by calculating the average pairwise variation of each reference gene from all the other reference gene candidates. In addition, it performs a ranking of the candidate genes by stepwise exclusion of the worst scoring gene and repeated recalculation of the average gene expression stability value. The designers of geNorm also stipulate that neither experimental conditions nor cell type affects the expression ratio of a "true" reference gene pair. This is based on the premise that the expression ratio of reference genes should be the same in all experimental samples. Hence, expression ratios of gene pairs were used as a measure of reference gene stability. The stability values calculated by GeNorm were used to rank gene expression in our study for potential reference genes for bovine neutrophils (Table 4).

The lower the stability value, the more likely that a candidate gene will be useful as a reference gene. Low stability values indicate stable gene expression [20]. Genes with a stability level $<0.5$ are considered stable [28]. Based on a stability level of $<0.5$ in geNorm analysis, PGK1 (Cq range, 1.74), B2M (Cq range, 2.62), GAPDH (Cq range, 2.73), YWHAZ (Cq range, 1.23), and G6PD (Cq range, 3.18) would be suitable as reference genes in beef calves, independent of Se-supple-
Table 4. Stability ranking of candidate reference genes in weaned beef calves fed for 6 or 7 weeks $0.96 \mathrm{mg} \mathrm{Se} / \mathrm{head} /$ day (Control), $18.76 \mathrm{mg} \mathrm{Se} /$ head/day (High Selenium), or combined groups, by the geNorm algorithm (lower stability values indicate more stable gene expression).

\begin{tabular}{cccccc}
\hline $\begin{array}{c}\text { Calves, control } \\
(\mathbf{n}=\mathbf{1 0})\end{array}$ & \multicolumn{2}{c}{$\begin{array}{c}\text { Calves, high } \\
\text { selenium }(\mathbf{n}=\mathbf{1 2})\end{array}$} & $\begin{array}{c}\text { Combined groups } \\
(\mathbf{n}=\mathbf{2 2})\end{array}$ \\
\hline \multicolumn{7}{c}{ Gene symbol and stability value } \\
\hline RPL19|SDHA & 0.268 & B2M|G6PD & 0.397 & PGK1|YWHAZ & 0.355 \\
G6PD & 0.357 & PGK1 & 0.419 & B2M & 0.444 \\
PGK1 & 0.410 & GAPDH & 0.450 & G6PD & 0.467 \\
YWHAZ & 0.427 & YWHAZ & 0.481 & GAPDH & 0.483 \\
B2M & 0.445 & RPL19 & 0.520 & RPL19 & 0.517 \\
GAPDH & 0.491 & SDHA & 0.587 & SDHA & 0.558 \\
HPRT & 0.540 & HPRT & 0.709 & HPRT & 0.668 \\
ACTB & 0.656 & ACTB & 0.850 & ACTB & 0.794 \\
\hline
\end{tabular}

mentation status. In contrast, four of the candidate reference genes would be excluded from consideration: ACTB (Cq range, 3.85), HPRT (Cq range, 3.39), SDHA (Cq range, 1.75), and RPL19 (Cq range, 1.83). Within the 5 acceptable genes B2M was not normally distributed. Similar to our reference gene study for ovine neutrophils [13], YWHAZ and GAPDH had suitable geNorm stability values. Compared with GAPDH, YWHAZ had a smaller $\mathrm{Cq}$ range, and better geNorm values (Table 4) for control and combined groups.

Using multiple reference genes rather than a single reference gene is likely to provide more robust and reliable results [20]. In the geNorm algorithm, the optimal number of reference genes is determined when addition of a further gene leads to a negligible reduction in the average of gene stability estimates. For control calves, the best pair of genes was RPL19|SDHA. For high Se calves, the best pair of genes was B2M|G6PD; however, $\mathrm{B} 2 \mathrm{M} \mid \mathrm{G} 6 \mathrm{PD}$ was not normally distributed (Shapiro-Wilk $\mathrm{W}=0.87 ; P=0.009$ ). Overall the best pair of reference genes was PGK1|YWHAZ $(22.85 \pm 0.39$; Cq range, 1.36).

\subsection{Norm Finder Analysis of Reference Genes}

The Norm Finder program uses a model-based approach that also estimates variation between sample subgroups. The program analyzes inter- and intra-group expression variation of potential reference genes. A stability value is calculated based on analysis of gene expression data, and the potential reference genes are then ranked. Lower values are assigned to the most stable genes. When Norm Finder was used to identify potential neutrophil reference genes in this study, YWHAZ, PGK1, and RPL19 ranked 
as the best choices (Table 5). The B2M gene did not rank as high in the high Se calves or the combined groups. Two of the candidate neutrophil reference genes would be excluded from consideration as they ranked consistently at or near the bottom four of the rank order: HPRT and ACTB. The commonly used reference gene ACTB was similarly a poor reference gene in WB cells of lactating dairy cows [18]. The PGK1 |YWHAZ gene combination had NormFinder stability values of 0.074 (control calves), 0.100 (high Se calves), and 0.089 (combined groups).

\subsection{BestKeeper Analysis of Reference Genes}

The program BestKeeper estimates the expression stability by performing a pairwise correlation analysis of each pair of candidate gene $\mathrm{Cq}$ values. It then calculates the geometric mean of the best suited genes. The weighted index is correlated with up to ten target genes using the same pairwise correlation analysis. When BestKeeper was used to find potential reference genes (Table 6), YWHAZ, PGK1, and RPL19 performed well in all groups, as did the PGK1|YWHAZ combination (stability value 0.30 for control calves and 0.32 for both high Se calves and combined groups). B2M was near the bottom of the rank order in Se-treated calves, in contrast to control calves. Similar to geNorm and NormFinder analyses, ACTB would be excluded from consideration as it ranked consistently at or near the bottom of the rank order. The latter also performed poorly as reference genes in WB cells of lactating dairy cows [18].

\subsection{Delta Cq Analysis of Reference Genes}

Finally, a delta $\mathrm{Cq}$ analysis [23] was performed; this ana-

Table 5. Stability ranking of candidate reference genes in weaned beef calves fed for 6 or 7 weeks $0.96 \mathrm{mg} \mathrm{Se} / \mathrm{head} /$ day (Control), $18.76 \mathrm{mg} \mathrm{Se/head/day} \mathrm{(High} \mathrm{Selenium),} \mathrm{or} \mathrm{com-}$ bined groups, by the NormFinder algorithm (lower stability values indicate more stable gene expression).

\begin{tabular}{cccccc}
\hline $\begin{array}{c}\text { Calves, control } \\
(\mathbf{n}=\mathbf{1 0})\end{array}$ & \multicolumn{3}{c}{$\begin{array}{c}\text { Calves, high } \\
\text { selenium }(\mathbf{n}=\mathbf{1 2})\end{array}$} & $\begin{array}{c}\text { Combined groups } \\
(\mathbf{n}=\mathbf{2 2})\end{array}$ \\
\hline \multicolumn{6}{c}{ Gene symbol and stability value } \\
\hline YWHAZ & 0.147 & YWHAZ & 0.128 & YWHAZ & 0.077 \\
B2M & 0.221 & PGK1 & 0.199 & PGK1 & 0.106 \\
PGK1 & 0.228 & RPL19 & 0.407 & RPL19 & 0.389 \\
RPL19 & 0.374 & GAPDH & 0.484 & B2M & 0.437 \\
G6PD & 0.393 & B2M & 0.513 & GAPDH & 0.505 \\
SDHA & 0.489 & G6PD & 0.558 & G6PD & 0.508 \\
HPRT & 0.563 & SDHA & 0.652 & SDHA & 0.572 \\
GAPDH & 0.565 & HPRT & 0.963 & HPRT & 0.899 \\
ACTB & 0.993 & ACTB & 1.241 & ACTB & 1.138 \\
\hline
\end{tabular}

Table 6. Stability ranking of candidate reference genes in weaned beef calves fed for 6 or 7 weeks $0.96 \mathrm{mg} \mathrm{Se} / \mathrm{head} /$ day (Control), $18.76 \mathrm{mg} \mathrm{Se} / \mathrm{head} /$ day (High Selenium), or combined groups, by the BestKeeper algorithm (lower stability values indicate more stable gene expression).

\begin{tabular}{cccccc}
\hline $\begin{array}{c}\text { Calves, control } \\
(\mathbf{n}=\mathbf{1 0})\end{array}$ & \multicolumn{2}{c}{$\begin{array}{c}\text { Calves, high } \\
\text { selenium }(\mathbf{n}=\mathbf{1 2})\end{array}$} & $\begin{array}{c}\text { Combined groups } \\
(\mathbf{n}=\mathbf{2 2})\end{array}$ \\
\hline \multicolumn{6}{c}{ Gene symbol and stability value } \\
B2M & 0.19 & YWHAZ & 0.33 & YWHAZ & 0.28 \\
YWHAZ & 0.22 & PGK1 & 0.39 & PGK1 & 0.39 \\
RPL19 & 0.36 & RPL19 & 0.42 & RPL19 & 0.40 \\
PGK1 & 0.38 & HPRT & 0.52 & B2M & 0.46 \\
HPRT & 0.43 & G6PD & 0.54 & HPRT & 0.50 \\
G6PD & 0.49 & GAPDH & 0.54 & SDHA & 0.54 \\
SDHA & 0.50 & SDHA & 0.56 & G6PD & 0.55 \\
ACTB & 0.59 & B2M & 0.57 & GAPDH & 0.56 \\
GAPDH & 0.59 & ACTB & 0.94 & ACTB & 0.84 \\
\hline
\end{tabular}

lysis is similar to the geNorm program in that pairs of genes are compared using $\mathrm{Cq}$ differences. The comparative delta $\mathrm{Cq}$ method compares the $\mathrm{Cq}$ value differences between two reference genes from different samples, and if the delta Cq value between pairs of genes remains constant for all samples tested, then those reference genes are either stably expressed or co-regulated. Potential reference gene candidates were compared in this study and ranked based on $\mathrm{Cq}$ value differences to determine those with the least variance. Results are shown in Table 7. The best choices for neutrophil reference genes were PGK1, YWHAZ, and RPL19. In our reference gene study for ovine neutrophils, YWHAZ and RPL19, along with G6PD and GAPDH, had the lowest delta Cq stability values [13]. Similar to geNorm, Norm-Finder, and BestKeeper analyses, ACTB would be excluded as a reference gene from consideration as it ranked consistently at or near the bottom four of the rank order. The PGK1| YWHAZ combination performed best with stability values of 0.45 (control calves), 0.55 (high Se calves), and 0.52 (combined groups).

\subsection{Stability of Neutrophil Reference Genes Evaluated in This Study}

Currently, there is no consensus as to what is the best program to evaluate potential reference genes. Therefore, we calculated the geometric mean of expression stability by four statistical approaches using the Geomean program. We found good agreement between the results with the four statistical approaches. The neutrophil reference genes, YWHAZ, PGK1, and RPL19, were consistently ranked among the top three most stable genes by all four 
programs (Table 8). Several conventional reference genes proved to be less reliable in neutrophils from beef calves, specifically ACTB, GYPC, HPRT, and TFRC.

Vandesompele et al. [20] suggested that normalization should be based on multiple references genes rather than a single gene to provide more robust and reliable results. The PGK1|YWHAZ combination performed best with Geomean values of 1.57 (control calves) and 1.00 (high Se calves) and 1.19 (combined groups), which is similar

Table 7. Stability ranking of candidate reference genes in weaned beef calves fed for 6 or 7 weeks $0.96 \mathrm{mg} \mathrm{Se} / \mathrm{head} /$ day (Control), $18.76 \mathrm{mg} \mathrm{Se/head/day} \mathrm{(High} \mathrm{Selenium),} \mathrm{or} \mathrm{combin-}$ ed groups, by the comparative delta Cq method (lower stability values indicate more stable gene expression).

\begin{tabular}{cccccc}
\hline \multicolumn{2}{c}{$\begin{array}{c}\text { Calves, control } \\
(\mathbf{n}=\mathbf{1 0})\end{array}$} & \multicolumn{2}{c}{$\begin{array}{c}\text { Calves, high } \\
\text { selenium }(\mathbf{n}=\mathbf{1 2})\end{array}$} & $\begin{array}{c}\text { Combined groups } \\
(\mathbf{n}=\mathbf{2 2})\end{array}$ \\
\hline \multicolumn{6}{c}{ Gene symbol and stability value } \\
\hline YWHAZ & 0.51 & PGK1 & 0.62 & PGK1 & 0.60 \\
PGK1 & 0.54 & YWHAZ & 0.67 & YWHAZ & 0.62 \\
B2M & 0.54 & RPL19 & 0.72 & RPL19 & 0.68 \\
G6PD & 0.59 & GAPDH & 0.77 & B2M & 0.71 \\
RPL19 & 0.59 & B2M & 0.77 & G6PD & 0.73 \\
SDHA & 0.64 & G6PD & 0.78 & GAPDH & 0.75 \\
GAPDH & 0.71 & SDHA & 0.86 & SDHA & 0.78 \\
HPRT & 0.73 & HPRT & 1.11 & HPRT & 1.04 \\
ACTB & 1.06 & ACTB & 1.34 & ACTB & 1.24 \\
\hline
\end{tabular}

Table 8. Stability ranking of candidate reference genes in weaned beef calves fed for 6 or 7 weeks $0.96 \mathrm{mg} \mathrm{Se} /$ head/day (Control), $18.76 \mathrm{mg} \mathrm{Se/head/day} \mathrm{(High} \mathrm{Selenium),} \mathrm{or} \mathrm{com-}$ bined groups, by the Geomean of ranking values for geNorm, NormFinder, BestKeeper and the comparative delta $\mathrm{Cq}$ method (lower stability values indicate more stable gene expression).

\begin{tabular}{cccccc}
\hline \multicolumn{1}{c}{$\begin{array}{c}\text { Calves, control } \\
(\mathbf{n}=\mathbf{1 0})\end{array}$} & \multicolumn{2}{c}{$\begin{array}{c}\text { Calves, high } \\
\text { selenium }(\mathbf{n}=\mathbf{1 2})\end{array}$} & $\begin{array}{c}\text { Combined groups } \\
(\mathbf{n}=\mathbf{2 2})\end{array}$ \\
\hline \multicolumn{6}{c}{ Gene symbol and stability value } \\
\hline YWHAZ & 1.78 & YWHAZ & 1.78 & YWHAZ & 1.19 \\
B2M & 2.45 & PGK1 & 1.86 & PGK1 & 1.41 \\
RPL19 & 2.78 & RPL19 & 3.57 & RPL19 & 3.57 \\
PGK1 & 3.13 & G6PD & 3.66 & B2M & 3.72 \\
SDHA & 3.98 & B2M & 3.76 & G6PD & 5.38 \\
G6PD & 4.36 & GAPDH & 4.43 & GAPDH & 5.89 \\
HPRT & 6.88 & HPRT & 6.73 & SDHA & 6.74 \\
GAPDH & 7.71 & SDHA & 7.00 & HPRT & 7.11 \\
ACTB & 8.74 & ACTB & 9.00 & ACTB & 9.00 \\
\hline
\end{tabular}

or better than any single gene (Table 8). Whereas PGK1 is an enzyme that is involved in glycolysis, YWHAZ plays a role in signal transduction by binding to phosphoserine containing proteins and is involved in many vital cellular processes, including metabolism, protein trafficking, apoptosis and cell cycle regulation [29]. More reliable qPCR data normalization should be achieved using a combination of genes from different biological pathways, rather than a single gene.

Our selection of reference genes for bovine neutrophils differs from results obtained for human neutrophils whereby recommended reference genes included TBP, ACTB, and SDHA [11] or GNB2L1, HPRT1, RPL32, $\mathrm{ACTB}$, and $\mathrm{B} 2 \mathrm{M}[10]$, and also differs from results we obtained for sheep neutrophils, whereby SDHA|G6PD and GAPDH|YWHAZ were the best pairs of references genes [13]. In lactating dairy cows, YWHAZ along with SDHA and 18S rRNA, were considered the most suitable reference genes for polymorphonuclear leukocytes [14]. In another lactating dairy cow study that investigated milk somatic cells, which consist predominantly of leukocytes, including lymphocytes, neutrophils (5\% to $25 \%$ ) and macrophages, the most stable reference genes included ACTB and GAPDH [17]. These results underscore the need to validate neutrophil reference genes under different experimental conditions.

\section{CONCLUSION}

A literature search for candidate genes in the species and cell type of interest provides a starting point for reference gene selection. Once potential reference genes have been screened for expression level and overall variability, candidate genes can be further analyzed for expression stability using four readily available software algorithms: geNorm, NormFinder, BestKeeper, and the comparative delta $\mathrm{Cq}$ method. The WB-neutrophil reference genes YWHAZ, PGK1, and RPL19 consistently ranked among the top four most stable genes under our experimental conditions. Several conventional reference genes proved to be less reliable, including ACTB, GYPC, HPRT, and TFRC. Multiple references genes rather than a single gene may provide more robust and reliable results. The best pair of reference genes in whole-blood neutrophils from beef calves was PGK1|YWHAZ.

\section{ACKNOWLEDGEMENTS}

Funded in part by Animal Health and Disease Project Formula Funds and the Agricultural Research Foundation, Oregon State University, Corvallis, OR 97331-4802, USA (J.A. Hall, Principal Investigator).

\section{REFERENCES}

[1] Bustin, S.A. (2000) Absolute quantification of mRNA us- 
ing real-time reverse transcription polymerase chain reaction assays. Journal of Molecular Endocrinology, 25, 169-193. http://dx.doi.org/10.1677/jme.0.0250169

[2] Suzuki, T., Higgins, P.J. and Crawford, D.R. (2000) Control selection for RNA quantitation. Biotechniques, 29, 332-337.

[3] Warrington, J.A., Nair, A., Mahadevappa, M. and Tsyganskaya, M. (2000) Comparison of human adult and fetal expression and identification of 535 housekeeping/ maintenance genes. Physiological Genomics, 2, 143-147.

[4] Thellin, O., Zorzi, W., Lakaye, B., De Borman, B., Coumans, B., Hennen, G., Grisar, T., Igout, A. and Heinen, E. (1999) Housekeeping genes as internal standards: Use and limits. Journal of Biotechnology, 75, 291-295. http://dx.doi.org/10.1016/S0168-1656(99)00163-7

[5] Huggett, J., Dheda, K., Bustin, S. and Zumla, A. (2005) Real-time RT-PCR normalisation; strategies and considerations. Genes \& Immunity, 6, 279-284. http://dx.doi.org/10.1038/sj.gene.6364190

[6] Hugejiletu, H., Bobe, G., Vorachek, W.R., Gorman, M.E., Mosher, W.D., Pirelli, G.J. and Hall, J.A. (2013) Selenium supplementation alters gene expression profiles associated with innate immunity in whole-blood neutrophils of sheep. Biological Trace Element Research, 154, 28-44. http://dx.doi.org/10.1007/s12011-013-9716-6

[7] Brinkmann, V., Reichard, U., Goosmann, C., Fauler, B., Uhlemann, Y., Weiss, D.S., Weinrauch, Y. and Zychlinsky, A. (2004) Neutrophil extracellular traps kill bacteria. Science, 303, 1532-1535. http://dx.doi.org/10.1126/science.1092385

[8] Buchanan, J.T., Simpson, A.J., Aziz, R.K., Liu, G.Y., Kristian, S.A., Kotb, M., Feramisco, J. and Nizet, V. (2006) DNase expression allows the pathogen group A Streptococcus to escape killing in neutrophil extracellular traps. Current Biology, 16, 396-400.

http://dx.doi.org/10.1016/j.cub.2005.12.039

[9] Beiter, K., Wartha, F., Albiger, B., Normark, S., Zychlinsky, A. and Henriques-Normark, B. (2006) An endonuclease allows Streptococcus pneumoniae to escape from neutrophil extracellular traps. Current Biology, 16, 401407. http://dx.doi.org/10.1016/j.cub.2006.01.056

[10] Zhang, X., Ding, L. and Sandford, A.J. (2005) Selection of reference genes for gene expression studies in human neutrophils by real-time PCR. BMC Molecular Biology, 6, 4. http://dx.doi.org/10.1186/1471-2199-6-4

[11] Ledderose, C., Heyn, J., Limbeck, E. and Kreth, S. (2011) Selection of reliable reference genes for quantitative realtime PCR in human T cells and neutrophils. BMC Research Notes, 4, 427. http://dx.doi.org/10.1186/1756-0500-4-427

[12] Peletto, S., Bertuzzi, S., Campanella, C., Modesto, P., Maniaci, M.G., Bellino, C., Ariello, D., Quasso, A., Caramelli, M. and Acutis, P.L. (2011) Evaluation of internal reference genes for quantitative expression analysis by real-time PCR in ovine whole blood. International Journal of Molecular Sciences, 12, 7732-7747. http://dx.doi.org/10.3390/ijms12117732

[13] Vorachek, W.R., Hugejiletu, Bobe, G. and Hall, J.A. (2013) Reference gene selection for quantitative PCR studies in sheep neutrophils. International Journal of Molecular Sciences, 14, 11484-11495.

http://dx.doi.org/10.3390/ijms140611484

[14] De Ketelaere, A., Goossens, K., Peelman, L. and Burvenich, C. (2006) Technical note: Validation of internal control genes for gene expression analysis in bovine polymorphonuclear leukocytes. Journal of Dairy Science, 89, 4066-4069.

http://dx.doi.org/10.3168/jds.S0022-0302(06)72450-X

[15] Bougarn, S., Cunha, P., Gilbert, F.B., Meurens, F. and Rainard, P. (2011) Technical note: Validation of candidate reference genes for normalization of quantitative PCR in bovine mammary epithelial cells responding to inflammatory stimuli. Journal of Dairy Science, 94, 2425-2430. http://dx.doi.org/10.3168/jds.2010-3859

[16] Saremi, B., Sauerwein, H., Danicke, S. and Mielenz, M. (2012) Technical note: Identification of reference genes for gene expression studies in different bovine tissues focusing on different fat depots. Journal of Dairy Science, 95, 3131-3138. http://dx.doi.org/10.3168/jds.2011-4803

[17] Varshney, N., Mohanty, A.K., Kumar, S., Kaushik, J.K., Dang, A.K., Mukesh, M., Mishra, B.P., Kataria, R., Kimothi, S.P., Mukhopadhyay, T.K., Malakar, D., Prakash, B.S., Grover, S. and Batish, V.K. (2012) Selection of suitable reference genes for quantitative gene expression studies in milk somatic cells of lactating cows (Bos indicus). Journal of Dairy Science, 95, 2935-2945. http://dx.doi.org/10.3168/jds.2011-4442

[18] Brym, P., Rusc, A. and Kaminski, S. (2013) Evaluation of reference genes for qRT-PCR gene expression studies in whole blood samples from healthy and leukemia-virus infected cattle. Veterinary Immunology and Immunopathology, 153, 302-307. http://dx.doi.org/10.1016/j.vetimm.2013.03.004

[19] Perez, R., Tupac-Yupanqui, I. and Dunner, S. (2008) Evaluation of suitable reference genes for gene expression studies in bovine muscular tissue. BMC Molecular Biology, 9, 79. http://dx.doi.org/10.1186/1471-2199-9-79

[20] Vandesompele, J., De Preter, K., Pattyn, F., Poppe, B., Van Roy, N., De Paepe, A. and Speleman, F. (2002) Accurate normalization of real-time quantitative RT-PCR data by geometric averaging of multiple internal control genes. Genome Biology, 3, RESEARCH0034.

[21] Andersen, C.L., Jensen, J.L. and Orntoft, T.F. (2004) Normalization of real-time quantitative reverse transcriptionPCR data: A model-based variance estimation approach to identify genes suited for normalization, applied to bladder and colon cancer data sets. Cancer Research, 64, 52455250. http://dx.doi.org/10.1158/0008-5472.CAN-04-0496

[22] Pfaffl, M.W., Tichopad, A., Prgomet, C. and Neuvians, T.P. (2004) Determination of stable housekeeping genes, differentially regulated target genes and sample integrity: BestKeeper-Excel-based tool using pair-wise correlations. Biotechnology Letters, 26, 509-515. http://dx.doi.org/10.1023/B:BILE.0000019559.84305.47

[23] Silver, N., Best, S., Jiang, J. and Thein, S.L. (2006) Selection of housekeeping genes for gene expression studies in human reticulocytes using real-time PCR. BMC Molecular Biology, 7, 33.

http://dx.doi.org/10.1186/1471-2199-7-33 
[24] Bustin, S.A., Benes, V., Garson, J.A., Hellemans, J., Huggett, J., Kubista, M., Mueller, R., Nolan, T., Pfaffl, M.W., Shipley, G.L., Vandesompele, J. and Wittwer, C.T. (2009) The MIQE guidelines: Minimum information for publication of quantitative real-time PCR experiments. Clinical Chemistry, 55, 611-622. http://dx.doi.org/10.1373/clinchem.2008.112797

[25] Tao, W., Mallard, B., Karrow, N. and Bridle, B. (2004) Construction and application of a bovine immune-endocrine cDNA microarray. Veterinary Immunology and Immunopathology, 101, 1-17.

http://dx.doi.org/10.1016/j.vetimm.2003.10.011

[26] Hall, J.A., Bobe, G., Hunter, J.K., Vorachek, W.R., Stewart, W.C., Vanegas, J.A., Estill, C.T., Mosher, W.D. and Pirelli, G.J. (2013) Effect of feeding selenium-fertilized alfalfa hay on performance of weaned beef calves. PLOS One, 8, e58188.

http://dx.doi.org/10.1371/journal.pone. 0058188
[27] Pfister, C., Tatabiga, M.S. and Roser, F. (2011) Selection of suitable reference genes for quantitative real-time polymerase chain reaction in human meningiomas and arachnoidea. BMC Research Notes, 4, 275. http://dx.doi.org/10.1186/1756-0500-4-275

[28] Hellemans, J., Mortier, G., De Paepe, A., Speleman, F. and Vandesompele, J. (2007) qBase relative quantification framework and software for management and automated analysis of real-time quantitative PCR data. Genome Biology, 8, R19. http://dx.doi.org/10.1186/gb-2007-8-2-r19

[29] Niemantsverdriet, M., Wagner, K., Visser, M. and Backendorf, C. (2008) Cellular functions of 14-3-3 zeta in apoptosis and cell adhesion emphasize its oncogenic character. Oncogene, 27, 1315-1319.

http://dx.doi.org/10.1038/sj.onc. 1210742 